\title{
Erika Pani, Para pertenecer a la gran familia mexicana: procesos de naturalización en el siglo XIX, México, El Colegio de México-Centro de Estudios Históricos, 2015, 204 pp. ISBN 978-607-462-713-8.
}

Durante los últimos años, los conceptos de nación y ciudadanía han sido frecuentemente abordados por los historiadores. Entre la amplia gama de estudios al respecto, la mayoría se ha volcado más al análisis de su construcción simbólica que al de su realidad, ya sea estructurada desde el Estado o desde sus componentes. El libro de Erika Pani, Para pertenecer a la gran familia mexicana: procesos de naturalización en el siglo $X I X$, aborda ambos rubros. Deja ver la idea de nacionalidad que tenían los mexicanos, los extranjeros y las autoridades del México decimonónico, a través del estudio de las normas mediante las cuales dichas autoridades delimitaron en términos prácticos al país y a sus ciudadanos, pues en el trámite analizado se observa lo que entendían y pretendían que fuera un mexicano, "las bases sobre las cuales, desde el poder, quiso fincarse la pertenencia política” (p. 19).

Para recibir como ciudadanos iguales a los foráneos, el Estado estableció leyes y reglamentos que reflejan la idealización de la comunidad política que se deseaba alcanzar. Si bien México no se caracterizó por haber recibido a muchos extranjeros (no pasaron de 0.78\% de la población del país a lo largo del siglo XIX), entre los cuales en realidad pocos llevaron a cabo el proceso de naturalización -le fue concedida apenas a poco más de $3800-$, se percibe al trámite como la prueba última de integración y asimilación de la cultura mexicana, así como la adquisición de derechos y obligaciones correspondientes. De esta forma, el trabajo de Pani resulta especialmente interesante pues tiene varias enfoques: ofrece la concepción de los mexicanos sobre su pertenencia al país; la imagen que de ellos tenían de los extranjeros; el ideal de nación que las autoridades pretendían alcanzar; el concepto que sobre dicha nación tenían los forasteros; y el que creían que las autoridades mexicanas querían que tuvieran.

Con base en las listas de cartas de naturalización otorgadas por la Secretaría de Relaciones Exteriores entre 1828 y 1917 (resguardadas por el Archivo Histórico Genaro Estrada de esa misma dependencia), Pani aborda el fenómeno desde el ámbito de las tres partes involucradas en él: el Estado y la legislación correspondiente; los miembros de la burocracia que la aplicaban según su entendimiento y arbitrio; y los extranjeros que iniciaban el trámite con la esperanza de pertenecer a la gran familia mexicana. El primer capítulo ofrece 
la óptica estatal por medio del análisis de las leyes y las autoridades participantes en los procesos de naturalización. En general, la clase política -más en los años inmediatos a la consumación de la independencia- solía hablar maravillas de la llegada de extranjeros pero, con el paso del tiempo, fue poco lo que se hizo para facilitar el proceso de mexicanización. El cúmulo de normas y leyes respectivas dejan ver que el tema era de importancia para las autoridades, pero el trámite terminó resultando largo y engorroso, toda vez que los extranjeros eran vistos en realidad con desconfianza, "más como objeto de suspicacia que como potenciales ciudadanos" (p. 26).

Esta tendencia de considerar al foráneo como un problema potencial no fue gratuita. Si bien en un principio quedó establecido el proceso de naturalización como un trámite sencillo, en el que eran necesarias tan sólo la voluntad del extranjero y la prueba de que se trataba de un individuo de bien, el tiempo y las experiencias negativas generaron la desconfianza. Más allá de los riesgos de mantener en el territorio a un posible disidente ideológico, que alterara aún más las de por sí agitadas aguas políticas del país, las autoridades entendieron pronto la peculiar dinámica de los extranjeros y su dinero. Muchos de ellos llegaban a desarrollar actividades empresariales que no siempre arrojaban los resultados esperados, lo que derivó en la insana costumbre de transformar reclamaciones económicas entre particulares en serios problemas internacionales. Es así como se explican las legislaciones sobre extranjería, colonización y expulsión de extranjeros, y la obligación que se les impuso de registrarse para obtener un pasaporte o carta de seguridad que les permitiera trasladarse dentro del país o entrar y salir de él. El Estado pretendió, por medio del trámite de naturalización, reservarse la prevención de conflictos políticos, económicos y diplomáticos.

Curiosamente, el mismo recelo hacia los forasteros contribuyó a que, una vez comenzada la década de 1830, los procesos de naturalización encontraran cierta estabilidad y comenzaran a simplificarse. A guisa de ejemplo, la generación liberal que subió al escenario político tras la caída de la última dictadura santannista empleó modos simples y peculiares para hacerse de ciudadanos: la Constitución de 1857 estableció que los extranjeros se convertirían en mexicanos al adquirir propiedades en el territorio de la República o tener hijos mexicanos, siempre que no manifestaran la voluntad de conservar su nacionalidad original al momento de registrar la transacción o del nacimiento del vástago. En otras palabras, las autoridades apostaron por la distracción, la apatía o el simple descuido para aumentar el número de mexicanos. 
Resulta interesante el análisis presentado de la ley de extranjería y naturalización creada por Ignacio L. Vallarta en 1886, que otorgó una mayor importancia a la voluntad del individuo por hacerse mexicano, pero hizo al trámite dependiente del visto bueno del juez ante quien el interesado comenzaba el proceso. Además, contemplaba un candado a la nacionalidad al establecer que quienes se encontraran en el extranjero por más de dos años sin licencia perderían su calidad de mexicanos. La nacionalidad pasó así a depender en buena medida de la sujeción del individuo al Estado. Por otra parte, dicha legislación otorgó mayor peso a los lazos sanguíneos que al lugar de nacimiento, lo que reflejaba, en palabras de la autora, "la visión de una comunidad política fincada en el pasado, en la familia y el origen y no en un proyecto de futuro compartido" (p. 48).

Pani señala con acierto la cantidad de personajes e instancias que se involucraban en la naturalización: la sociedad misma donde el foráneo solicitante y su familia se desenvolvían, pues podía bastar una manifestación negativa de los vecinos para que las solicitudes fueran negadas; el poder judicial que, al aportar los antecedentes legales del peticionario, solía trabar o destrabar el trámite; la Iglesia, no sólo porque era exigido practicar el credo católico, sino porque el matrimonio con una mexicana $-\mathrm{o}$ mexicano la menor de las veces- fue el recurso por excelencia de los extranjeros para asegurar el éxito de su solicitud, de modo que las autoridades eclesiásticas podían ser mediadoras o el fiel de la balanza entre el solicitante y el Estado. El elemento internacional también debe considerarse, pues hacerse de nuevos ciudadanos implicaba arrebatarlos a otros países, lo que en más de una ocasión trajo conflictos con naciones que reclamaban a sus naturales.

En el segundo capítulo, Pani aborda la mecánica burocrática de la naturalización, dando cuenta del extremo cuidado con que el proceso era llevado por los encargados del proceso. Si bien durante el último tercio del siglo XIX las naturalizaciones aumentaron, las autoridades se volvieron menos complacientes, como lo ilustra la petición de descripción física y fotografía que se hizo a los solicitantes. En la práctica, los funcionarios adquirieran gran importancia pues, según el apego a su actividad, la simpatía que el peticionario pudiera inspirarle, la inclinación que mostrara hacia determinada ideología política o su cercanía a algún personaje de importancia de la escena nacional, el proceso podía naufragar o llegar a buen puerto, inclusive con faltas y omisiones en la documentación necesaria. En el mismo sentido, ya que la legislación solicitaba "buena conducta” a los peticionarios, los funcionarios se erigieron como "guardianes de la integridad moral de la nación” (p. 82), quedando en sus 
manos el discernir cuáles ideas, actividades, negocios y creencias eran dignos de ser recibidos. Las normas, entonces, eran tan elásticas o estrictas como los burócratas lo desearan o entendieran. De ello dan cuenta las pocas mujeres que solicitaron la nacionalización —sólo a 21 les fue concedida, según los registros-, en cuyos casos el papel de los oficiales mexicanos parece haber consistido en encontrar razones para negárselas.

En el último capítulo la autora expone quiénes fueron los extranjeros que decidieron convertirse en mexicanos. Basada en los argumentos presentados, las características de los peticionarios y los resultados de los procesos, ofrece un sugerente perfil de aquellos a los que el país abrió sus puertas y de los motivos que tuvieron para solicitar su mexicanización. Las cifras presentadas resultan igualmente interesantes. Españoles, estadunidenses, guatemaltecos y chinos fueron los que en mayor número concluyeron el trámite con éxito. El caso de estos últimos, como bien señala Pani, pone en entredicho el que la naturalización significara la prueba última de integración y asimilación del foráneo a la nación receptora, toda vez que en muchas ocasiones los asiáticos la realizaban con la intención de trasladarse a Estados Unidos. Asimismo, queda claro que para explicar los picos de las naturalizaciones otorgadas, de mediados de la década de 1840 -en especial 1844-y de 1870, finales de la de 1890, principios de los 1900 y hacia el estallido revolucionario -1908-1910_, deben tomarse en cuenta por igual las circunstancias mexicanas y de los países de origen de los solicitantes.

La autora distingue dos dinámicas generales entre los que realizaron el proceso de naturalización: la de reacción, cuando decretos legales afectaban sus intereses -como la ley de 1843 que prohibía a los foráneos comerciar al menudeo-, y la de aprovechamiento, cuando algunas instituciones mexicanas facilitaban la naturalización para conservar a sus empleados como sucedió, entre 1908 y 1910, cuando la Secretaría de Fomento y Obras Públicas ordenó mexicanizar a sus trabajadores extranjeros de las costas de Baja California y Quintana Roo.

Las imágenes insertadas en el capítulo son muy enriquecedoras y su análisis deja ver una curiosa ironía: lejos de reflejar un retrato fiel de los solicitantes, lo que había sido el objeto de las autoridades mexicanas al requerirles fotografías, ofrecían una pintura alejada de la realidad gracias a algunas exageraciones que pensaban que fortalecerían su solicitud por hacerlos parecer más adaptados a la sociedad mexicana y sus costumbres. Por ello, la gran cantidad de comerciantes, marinos, agricultores, artesanos, empleados y propietarios que pretendieron formar parte de la gran familia mexicana, dejaron en los papeles de sus procesos de naturalización una pintura poco fiel de sí mismos. 
Pani concluye su trabajo señalando las transformaciones de los procesos de naturalización provocados por la lucha revolucionaria de la segunda década del siglo pasado. La característica principal fue la confusión respecto a las autoridades competentes y sus resoluciones. En muchos casos no quedó claro qué hacer con las naturalizaciones concedidas por los gobiernos que se sucedieron durante los años de la contienda civil. De cualquier forma, en la legislación correspondiente se advierten más continuidades que cambios, siendo de éstos el más significativo el plasmado en el artículo 30 de la Constitución de 1917, que estableció que serían mexicanos todos los nacidos en el territorio de la República, en sus embarcaciones y en sus aeronaves. Con ello, apunta la autora, se echó por tierra la costumbre decimonónica de otorgar preponderancia a los lazos sanguíneos, la tradición y el pasado por encima del lugar de nacimiento.

Para pertenecer a la gran familia mexicana representa una aportación importante al estudio del México decimonónico y de los vericuetos que sus dirigentes debieron sortear para fortalecer un Estado en proceso de construcción, que enfrentaba serios problemas internos y externos, y cuyos ciudadanos solían escaparse fácilmente de su dominio político. Tan sólo puede echarse un poco de menos un listado de las normas correspondientes a la ciudadanía y la naturalización, que aclarara su contenido y los cambios que sufrió dentro de las circunstancias mexicanas del caótico siglo XIX.

Al final, una de las valiosas conclusiones del trabajo apunta que los procesos de naturalización reflejan los esfuerzos por consolidar un aparato de gobierno fuerte, esfuerzos que recayeron en quizá el único elemento en que podía afirmarse la autoridad del Estado: los extranjeros que deseaban pertenecer a la comunidad política nacional. Con ellos se pretendió dar forma a una sociedad, o al menos parte de ella, sobre la que podía asegurarse control.

Víctor A. Villavicencio Navarro Centro de Enseñanza para Extranjeros Universidad Nacional Autónoma de México victorvillavicencion@hotmail.com 